\title{
A COMPARATIVE ANALYSIS OF VIRTUAL AND TRADITIONAL LEARNING ENVIRONMENT IN PAKISTAN
}

\author{
By \\ Ayesha Mehboob \\ N. A. Sangi ${ }^{\bullet \bullet}$
}

\section{Abstract}

Online education is increasingly becoming common in higher education for supporting traditional education as well as emerging as an opportunity for delivering entire education online. In Online education, multimedia materials are used to support learning and the ability to adapt the course content to meet a wider range of learner interests and abilities. This research investigates the satisfaction and performance of the students in TLE and VLE and also finds differences in gender based students' satisfaction and performance. Further, the preferences of the students in selecting their Learning Environment are analysed. Data have been collected from four educational institutions with a sample of size 200 duly taken for consideration. The findings portray that maximum students are satisfied with their learning environment and performing well in their respective environment. However, most male students especially of TLE want to switch over from TLE to VLE due to certain reasons. Management or higher authorities in TE may try a launch an optional parallel VE to attract more students and to give an alternate option for their traditional student to perform better.

\section{Keywords}

Virtual Leaning Environment (VLE), Traditional Learning Environment (VLE), Students' satisfaction, Students' performance, learning environment difference.

\section{Introduction}

Computers have become one of the essential elements of our modern lives where information and communication technologies (ICT) have captured the interest of many people from different fields. There are a number of studies on technology integration for educational purposes and it seems that there is a growing agreement on the benefits of utilizing the Virtual Learning together with the Traditional classrooms interaction. In the perfect learning field, the university educations shape the knowledge basis for basic professional understanding and growth of new skills for full information. In this rational globe Virtual Learning has means in the universities getting the most benefits from the active internet applications. Such succession have impulsive changes in the web from a usual text-only standard to increase multimedia communication system, which in turn provided momentum for basic changes in the delivery mechanisms of rational information, Online courses and training programmes Rovai, A (2002).

The past few decades had seen a marvelous enhancement in media technologies, possibilities of video recording, image compression its broadcast through satellite

\footnotetext{
- The writer is MS Scholar in the International Islamic University, Islamabad.

• The writer is working as Vice Chancellor, Allama Iqbal Open University, Islamabad.
} 
communication and its outstanding value reception through TV, movies and have video phones over the other parts of the world. These developments also directly influenced the teaching and learning methodologies all over the world.

Virtual learning environment (VLE) is currently a hot research and development area. A large number of universities and institutions have started providing VLE to the students around the world. The dimensions of distance and time both have been reduced. The students can now stay in their most important job, home and can still perform their desire for seeking knowledge from the West and East, North and South. In this regard VLE is much more convenient and fast. The main concern which is required for VLE is the use of electronic media (Manan, S.K. and Mohamad, R. (2003)).

Virtual learning is now a sizzling research and development area. Benefits of Virtual learning environment are clear: classroom independence and platform independence. Online course installed and supported in one place can be used by thousands of students all over the world that are equipped with any sort of Internet-connected computer. Thousands of Online courses and other important application for delivering the lecture are available on different web site. VLE is a non-traditional system of education in which student and instructor both are separated by distance and in some cases.

Sangi (2005) said that the use of IT has created a major shift in educational services in distance as well traditional learning environment. Changes and improvements in IT infrastructure, sported by multimedia computing and ICT will probably make lecture and computer laboratories much more effective and efficient. Although multimedia and internet has provided many opportunities, but there are many challenges to the courseware developer. One should understand course development requires a methodology according to the subjects to be taught, the students to be addressed and for specific learning.

The vastness of knowledge acquisition has its own advantages as well as disadvantages. Therefore, an investigation into comparative analysis of traditional and virtual learning environment by itself has become a source of research all over the world. Pakistan is a developing country. Limited research is available on the learning approaches in Pakistan. A couple of studies are available on VLE and TLE. But no study has been yet conducted to determine the comparison between them. The present research article is narrowly being focused on student's satisfaction and performance towards either for virtual or traditional learning environment; they feel as to which course system would be more satisfactory and efficient. This paper attempts to accomplish the following goals:

1. To find out that which learning environment is preferred by the students.

2. To check whether students are satisfied with their respective learning environment.

3. To examine whether the performance of students depend upon the learning environment.

\section{Virtual Learning Environment}

A virtual learning environment (VLE) is a system designed to support teaching and learning in an educational setting, as distinct from a Managed Learning Environment, (MLE) 
where the management is brought into focus. A VLE will normally work over the Internet and provide a collection of tools such as those for assessment (particularly of types that can be marked automatically, such as multiple choice), communication, uploading of content, return of students' work, peer assessment, administration of student groups, collecting and organizing student grades, questionnaires, tracking tools, etc. New features in these systems include wikis, blogs, RSS and 3D virtual learning spaces.

\section{Traditional Learning Environment}

Traditional education or back-to-basics refers to long-established customs found in schools that society has traditionally deemed appropriate. Some forms of education reform promote the adoption of progressive education practices, a more holistic approach which focuses on individual students' needs and self-expression. According to reformers, the traditional teachercentered methods focused on rote learning and memorization must be abandoned in favor of student-centered and task-based approaches to learning. However, many parents and conservative citizens are concerned with the maintenance of objective educational standards based on testing, which favors a more traditional approach.

Depending on the context, the opposite of traditional education may be progressive education, modern education (the education approaches based on developmental psychology), or alternative education.

\section{Data Collection and Sample}

The data collected through administration of survey from organizations in the educational sectors of Pakistan. Stratified sampling method used for conduct of survey. Two strata were made. Each strata consist of two universities. In strata one the universities having Virtual learning system (AIOU and VU) were included while in second strata the universities having Traditional learning system (IIUI and MUST) were included. Two hundred questionnaires distributed in these universities. An Online questionnaire was also launched on website www.itzmeaamir.com/vle/index.php and got filled by the students' of AIOU whereas from other universities the researchers personally collected filled questionnaires. Students had fully freedom to reply as per their desire. There was no any pressure on them. The questionnaire consist of three sections: (a) Learning Environment (VLE and TLE); (b) Satisfaction of students; and (c) Performance of the students. The questionnaires were filled by the students during their class sessions. As already mentioned, sample size consist of 200 respondents. These two hundred respondents were selected on simple random based and a sample of 100 each was taken from both stratas. The students, specially those who were enrolled in BBA, MBA, BS(CS) programmes were taken into account. Analytical tools such as mean, median mode, standard deviation and chi- square were applied to test the hypotheses using statistical software SPSS version 16.0

\section{Population}

\begin{tabular}{|l|c|}
\hline \multicolumn{1}{|c|}{ Universities } & Sample \\
\hline Allama Iqbal Open University Islamabad & 41 \\
\hline International Islamic University Islamabad & 50 \\
\hline Mirpur University of Science and Technology & 50 \\
\hline Virtual University Islamabad Total & 59 \\
\hline \multicolumn{1}{|c|}{$\quad$ 200 } \\
\hline
\end{tabular}


Data Analysis

\begin{tabular}{|c|c|c|c|c|}
\hline Virtual Learning Environment & Mean & Median & Mode & S.D \\
\hline $\begin{array}{l}\text { I like the use of technology for online learning } \\
\text { environment }\end{array}$ & 3.67 & 4.00 & 4.00 & 1.01 \\
\hline I like online presentation & 4.43 & 5.00 & 5.00 & .76 \\
\hline I am comfortable in asking online questions & 3.75 & 4.00 & 4.00 & .957 \\
\hline I can well communicate with teacher on web site & 3.67 & 4.00 & 5.00 & 1.11 \\
\hline $\begin{array}{l}\text { I am able to perform lab work without the help of } \\
\text { teacher }\end{array}$ & 3.26 & 3.00 & 3.00 & .836 \\
\hline I learn more from the web resources. & 3.54 & 4.00 & 4.00 & .783 \\
\hline $\begin{array}{l}\text { Material available on web suggested has } \\
\text { improved my learning }\end{array}$ & 3.85 & 4.00 & 4.00 & .946 \\
\hline $\begin{array}{l}\text { An online session is an efficient means of } \\
\text { communicating with other students in course }\end{array}$ & 3.54 & 4.00 & 4.00 & 1.03 \\
\hline An online course allows for social interaction. & 3.53 & 4.00 & 4.00 & .881 \\
\hline $\begin{array}{l}\text { I want face-to-face interaction with teacher during } \\
\text { lecture }\end{array}$ & 3.22 & 3.00 & 3.00 & .882 \\
\hline
\end{tabular}

In virtual learning environment most students are in favour of online presentation (mean 4.43, median and mode 5 with standard deviation 0.76). The trend is toward strongly agreed. Similarly, the response of "I can well communicate with teacher on website" is towards strongly agree as mean 3.67 median 4.00 but mode 5.00 with standard deviation 1.11 which is not very high. While remaining responses are in range of neutral and agree. Trend going towards 'agree' in all these responses.

In traditional learning environment (TLE) the response for statement "I like the use of technology for class learning environment" is very high and trend is towards 'strongly agree' as mean 4.15, median and mode 5.00 with standard deviation 1.15. Similarly trend is toward 'strongly agree' for statements "I like class presentation", "I learning more from the class lectures" and for "I want face to face interaction with teacher during lectures. The response of remaining statements is between 'neutral' and 'agree'.

I prefer learning environment

\begin{tabular}{|l|l|c|c|c|c|}
\hline \multicolumn{2}{|c|}{} & Frequency & Percent & Valid Percent & Cumulative Percent \\
\hline \multirow{3}{*}{ Valid } & VLE & 131 & 65.5 & 65.5 & 65.5 \\
\cline { 2 - 6 } & TLE & 69 & 34.5 & 34.5 & 100.0 \\
\cline { 2 - 6 } & Total & 200 & 100.0 & 100.0 & \\
\hline
\end{tabular}

About $65.5 \%$ percent of the students preferred VLE while only $34.5 \%$ responded in favour of TLE.

Satisfaction in Virtual Learning Environment

\begin{tabular}{|c|c|c|c|c|}
\hline Satisfaction & Mean & Median & Mode & S.D \\
\hline I am satisfied with the amount of time required for & 4.00 & 4.00 & 4.00 & .858 \\
\hline
\end{tabular}




\begin{tabular}{|l|l|l|l|l|}
\hline this course & & & & \\
\hline $\begin{array}{l}\text { I am satisfied with the learning that occurred in } \\
\text { Course }\end{array}$ & 3.56 & 4.00 & 4.00 & .879 \\
\hline I am more satisfied with the class discussion & 3.61 & 4.00 & 4.00 & .897 \\
\hline I am satisfied from teaching methods & 3.73 & 4.00 & 5.00 & 1.22 \\
\hline I am satisfied with teacher's evaluation & 3.76 & 4.00 & 4.00 & .877 \\
\hline
\end{tabular}

Overall mean $=3.73$

Satisfaction in Traditional Learning Environment

\begin{tabular}{|l|l|l|l|l|}
\hline \multicolumn{1}{|c|}{ Satisfaction } & Mean & Median & Mode & S.D \\
\hline $\begin{array}{l}\text { I am satisfied with the amount of time required for } \\
\text { this course }\end{array}$ & 3.35 & 4.00 & 4.00 & 1.19 \\
\hline $\begin{array}{l}\text { I am satisfied with the learning that occurred in } \\
\text { course }\end{array}$ & 3.70 & 4.00 & 4.00 & 1.11 \\
\hline I am more satisfied with the class discussion & 3.69 & 4.00 & 4.00 & 1.04 \\
\hline I am satisfied from teaching methods & 3.62 & 4.00 & 4.00 & 1.12 \\
\hline I am satisfied with teacher's evaluation & 3.36 & 3.50 & 4.00 & 1.16 \\
\hline
\end{tabular}

Overall mean $=3.54$

In VLE the students are more satisfied with the time required for their particular course and also much satisfied with teachers' evaluation. Overall mean satisfaction score for virtual learning is 3.73 while for traditional learning its 3.54 .

Performance in Virtual Learning Environment

\begin{tabular}{|l|c|c|c|c|}
\hline \multicolumn{1}{|c|}{ Performance } & Mean & Median & Mode & S.D \\
\hline Course is successfully completed in time & 3.55 & 4.00 & 4.00 & 1.05 \\
\hline I get knowledge from the subject & 3.93 & 4.00 & 4.00 & .807 \\
\hline I obtain expected grades & 3.75 & 4.00 & 4.00 & .936 \\
\hline I have improved my learning skills & 4.24 & 4.00 & 5.00 & .900 \\
\hline I feel difficulties in learning & 3.97 & 4.00 & 5.00 & 1.14 \\
\hline
\end{tabular}

Overall mean $=3.89$

Performance in Traditional Learning Environment

\begin{tabular}{|l|c|c|c|c|}
\hline \multicolumn{1}{|c|}{ Performance } & Mean & Median & Mode & S.D \\
\hline Course is successfully completed in time & 3.41 & 4.00 & 4.00 & 1.35 \\
\hline I get knowledge from the subject & 3.87 & 4.00 & 4.00 & .872 \\
\hline I obtain expected grades & 3.65 & 4.00 & 4.00 & 1.07 \\
\hline I have improved my learning skills & 4.00 & 4.00 & 4.00 & .852 \\
\hline I feel difficulties in learning & 3.16 & 3.00 & 4.00 & 1.07 \\
\hline
\end{tabular}

Overall mean $=3.61$ 
In the case of analysis of performance, the highest score is for statement "I have improved my learning skills". The mean score for this statement in VLE is 4.24 with median 4.00 and mode 5.00, while standard deviation is 0.900 . The mean score for the same statement in TLE is 4.00 , median 4.00 and mode also 4.00 with standard deviation of 0.852 . The mean score for remaining statements lies in between 3.00 to 4.00 in both learning environment. The standard deviation is also very consistent. The overall mean for VLE is 3.89 and for TLE 3.61.

\section{Findings}

Analysis of data yielded the following results:

1. A reasonable number of respondents preffered the VLE environment, especially male student, even those who learning in TLE preferred VLE.

2. The students studying in VLE are more satisfied from the learning environment then the student those who learning in TLE.

3. The performance of VLE students is better than students of TLE.

\section{Discussion}

The virtual learning environment is getting popular day by day as it has much flexibility in its system like time management, duration, learning methodologies, etc. Male students specially prefer this learning environment as in developing countries like Pakistan. The male population is considered to be the earning figure. The male people can continue their learning activities along with job in VLE so they prefer it. VLE is also popular in female as in our country there are many social constraints. In some areas, the people don't like to send their daughters to colleges or universities so in those areas especially VLE can play an important role.

From results it also becomes clear that the students of VLE are more satisfied with teachers' evaluation while the students of TLE are not much satisfied. The reason may be that in TLE there is face to face teaching-learning process and the teachers may get biased due to some certain reasons and likeness and dis-likeness get involved but in VLE there is not any type of face to face interaction so biasedness can't be developed.

Communication technology is developing day by day and this technology is facilitating everyone. In VLE the ICT play vital role and that's why the students want to use ICT for learning process.

In VLE the students are facing more problems than the TLE; the reason may be as in TLE there is face to face contact with teacher so the problems get solved quicker than VLE where there is no direct contact with teacher. Also the ICT is on developing stages and there are many technical problems still in this technology. However, with the passage of time it can be enhanced and more developed.

\section{Recommendations}

1. The Higher Education Commission (HEC) should take necessary steps for the establishment of Virtual Leaning institutes and Universities so that VLE could be more approachable and assessable in all areas. 
2. The Universities should start Virtual Education in parallel to Traditional Education so that students get an alternate to complete their education more easily.

3. The VLE can increase the literacy rate of our country so necessary steps should be taken for its nourishment not only at high level education but also at secondary level.

4. Use of latest communication technology can make VLE more attractive and assessable for everyone so ICT should be enhanced.

5. Traditional learning is also very important and has many positive aspects. As such, it should also be continued. However, it should also based on latest communication technology.

\section{REFERENCES}

Manan, S.K. and Mohamad, R. (2003). Kajian Mengenai Pencapaian Akademik Pelajar-Pelajar UITM Shah Alam: Satu Analisa Perbandingan Antara Jantina. Social and Managerial Research Journal, 1: 141-55.

Nazir A. Sangi (2005).Engineering quality learning through ICT: An AIOU model for online education and research. ICDE International Conference, 19-23.

Rovai, A (2002). In search of higher persistence rates in distance education online programs. Internet and Higher Education, 1-16. http://en.wikipedia.org/wiki/Virtual_learning_environment http://en.wikipedia.org/wiki/Traditional_education

Please tick $(\sqrt{ })$ the appropriate checkbox below.

ANNEX-A

\section{Gender:}

$\square$ Male $\quad \square$ Female

Age:

18-22 $\square$ 23-27

28-32 $\square 32$ and Above

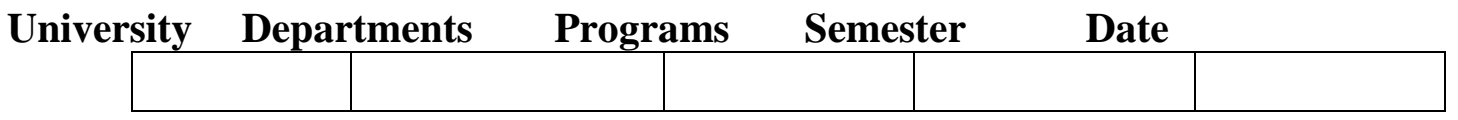

\begin{tabular}{|c|c|c|c|c|c|}
\hline \multirow{3}{*}{ Scale } & Strongly & Disagree & Neutral & Agree & Strongly \\
& Disagree & $\mathbf{2}$ & $\mathbf{3}$ & $\mathbf{4}$ & Agree \\
& $\mathbf{1}$ & & & & 5 \\
\hline
\end{tabular}

Part A: Virtual /Traditional Learning Environment

\begin{tabular}{|l|l|l|l|l|l|}
\hline $\begin{array}{l}\text { I like the use of technology for } \\
\text { online/class room learning }\end{array}$ & 1 & 2 & 3 & 4 & 5 \\
\hline I like online/class room presentations & 1 & 2 & 3 & 4 & 5 \\
\hline
\end{tabular}




\begin{tabular}{|l|c|c|c|c|c|}
\hline $\begin{array}{l}\text { I am comfortable in asking questions in } \\
\text { class/online }\end{array}$ & 1 & 2 & 3 & 4 & 5 \\
\hline $\begin{array}{l}\text { I can well communicate with teacher } \\
\text { on website/class room }\end{array}$ & 1 & 2 & 3 & 4 & 5 \\
\hline $\begin{array}{l}\text { I am able to perform lab/class work } \\
\text { without the help of teacher }\end{array}$ & 1 & 2 & 3 & 4 & 5 \\
\hline $\begin{array}{l}\text { I am able to learn more from the web } \\
\text { resources/class lectures }\end{array}$ & 1 & 2 & 3 & 4 & 5 \\
\hline $\begin{array}{l}\text { Material provided on web/in class room } \\
\text { suggested by teacher has improved my } \\
\text { learning }\end{array}$ & 1 & 2 & 3 & 4 & 5 \\
\hline $\begin{array}{l}\text { An online/class session is an efficient } \\
\text { means of communicating with other } \\
\text { students in course }\end{array}$ & 1 & 2 & 3 & 4 & 5 \\
\hline $\begin{array}{l}\text { An online course/class meetings allows } \\
\text { for social interaction. }\end{array}$ & 1 & 2 & 3 & 4 & 5 \\
\hline $\begin{array}{l}\text { I want face- to- face interaction with } \\
\text { teacher during lecture }\end{array}$ & 1 & 2 & 3 & 4 & 5 \\
\hline
\end{tabular}

Part B: Students' Satisfaction

\begin{tabular}{|l|c|c|c|c|c|}
\hline $\begin{array}{l}\text { I am satisfied with the amount of time } \\
\text { required for this course }\end{array}$ & 1 & 2 & 3 & 4 & 5 \\
\hline $\begin{array}{l}\text { I am satisfied with the learning that } \\
\text { occurred in course }\end{array}$ & 1 & 2 & 3 & 4 & 5 \\
\hline $\begin{array}{l}\text { I am more satisfied with the class } \\
\text { discussions }\end{array}$ & 1 & 2 & 3 & 4 & 5 \\
\hline I am satisfied from teaching methods & 1 & 2 & 3 & 4 & 5 \\
\hline I am satisfied with teacher's evaluation & 1 & 2 & 3 & 4 & 5 \\
\hline
\end{tabular}

Part C: Students' Performance

\begin{tabular}{|l|c|c|c|c|c|}
\hline $\begin{array}{l}\text { Course is successfully completed in } \\
\text { time }\end{array}$ & 1 & 2 & 3 & 4 & 5 \\
\hline I get knowledge from the subject & 1 & 2 & 3 & 4 & 5 \\
\hline I obtain expected grades & 1 & 2 & 3 & 4 & 5 \\
\hline I have improved my learning skills & 1 & 2 & 3 & 4 & 5 \\
\hline I feel difficulties in learning & 1 & 2 & 3 & 4 & 5 \\
\hline
\end{tabular}

\section{I prefer}

Virtual Learning Environment

I am more satisfied with

$\square$ Virtual Learning Environment

I can perform better in

$\square$ Virtual Learning Environment

\section{Traditional Learning Environment}

Traditional Learning Environment

Traditional Learning Environment 
Percentage of marks obtained in last semester:

ANNEX-B

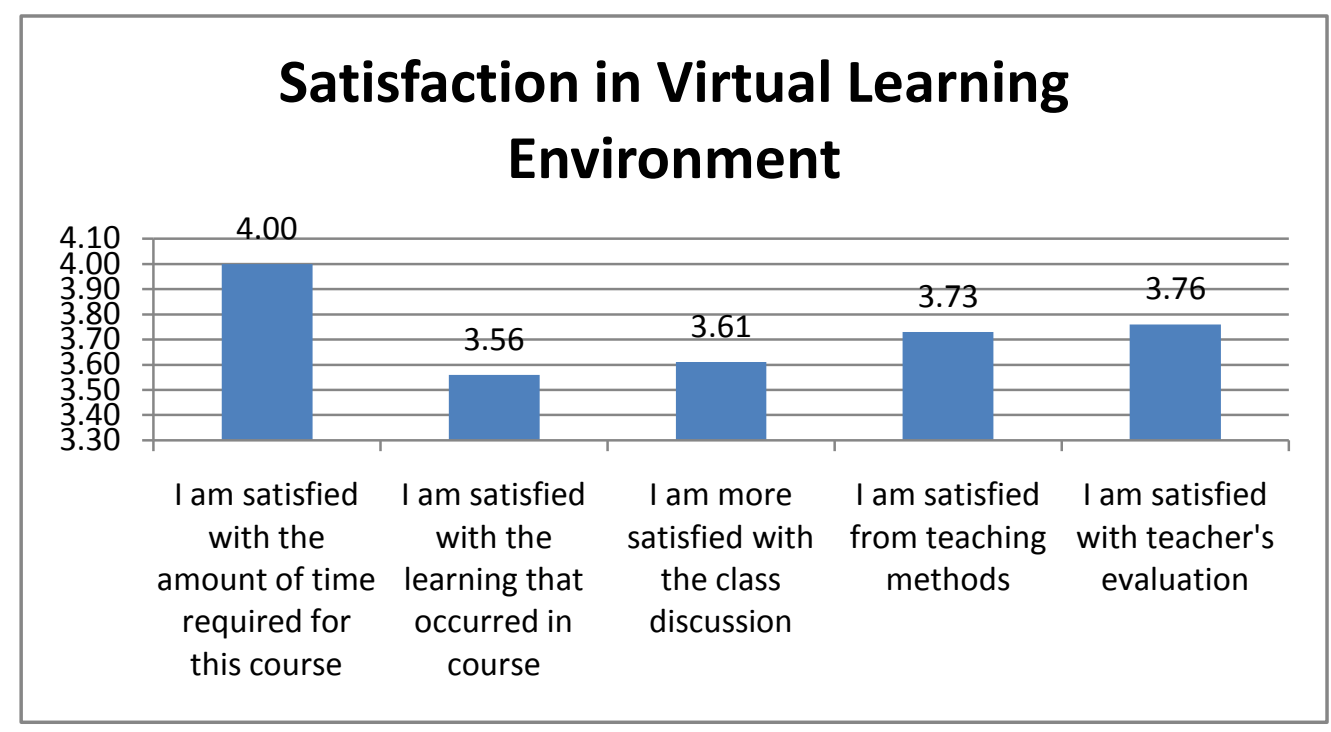

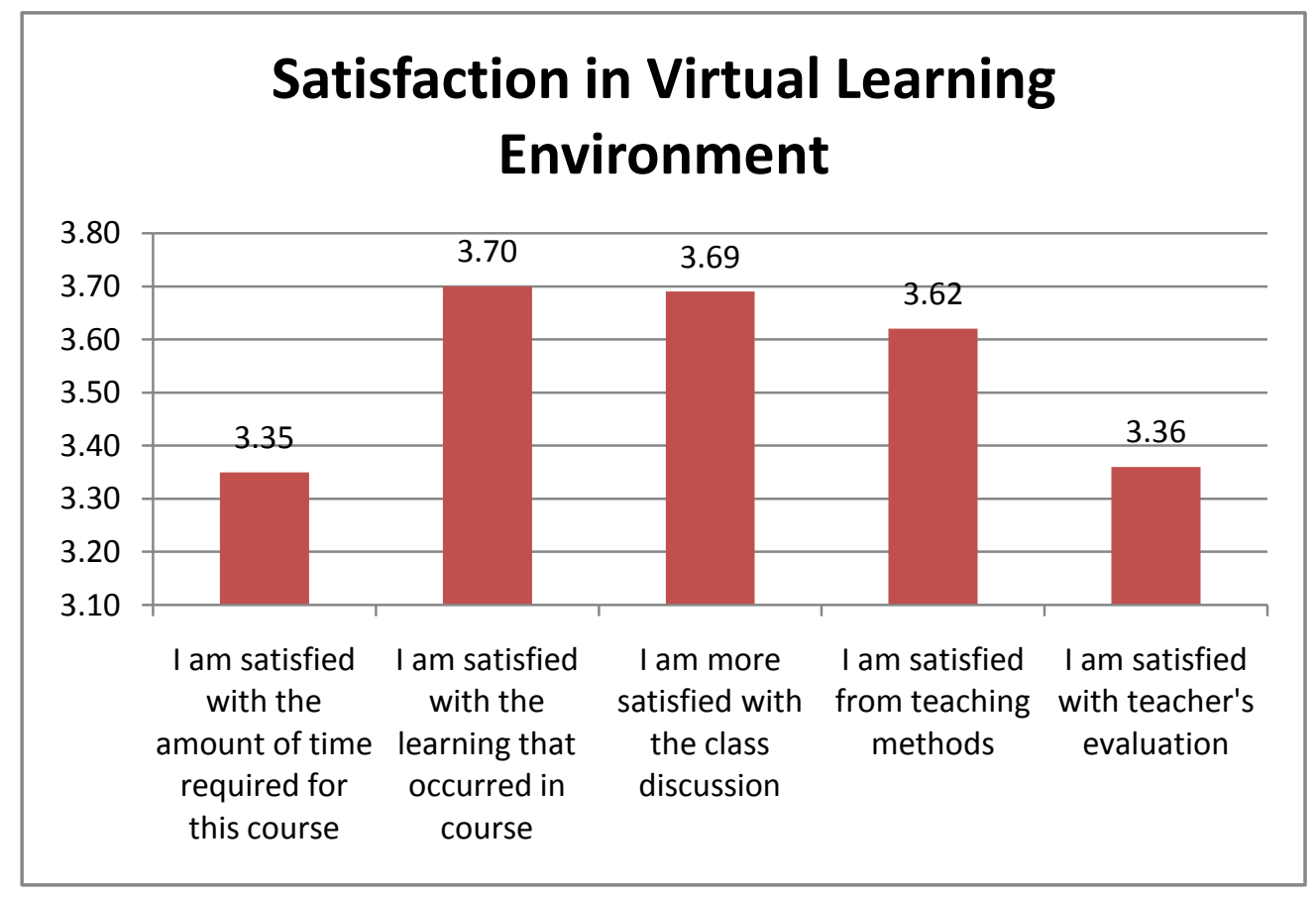



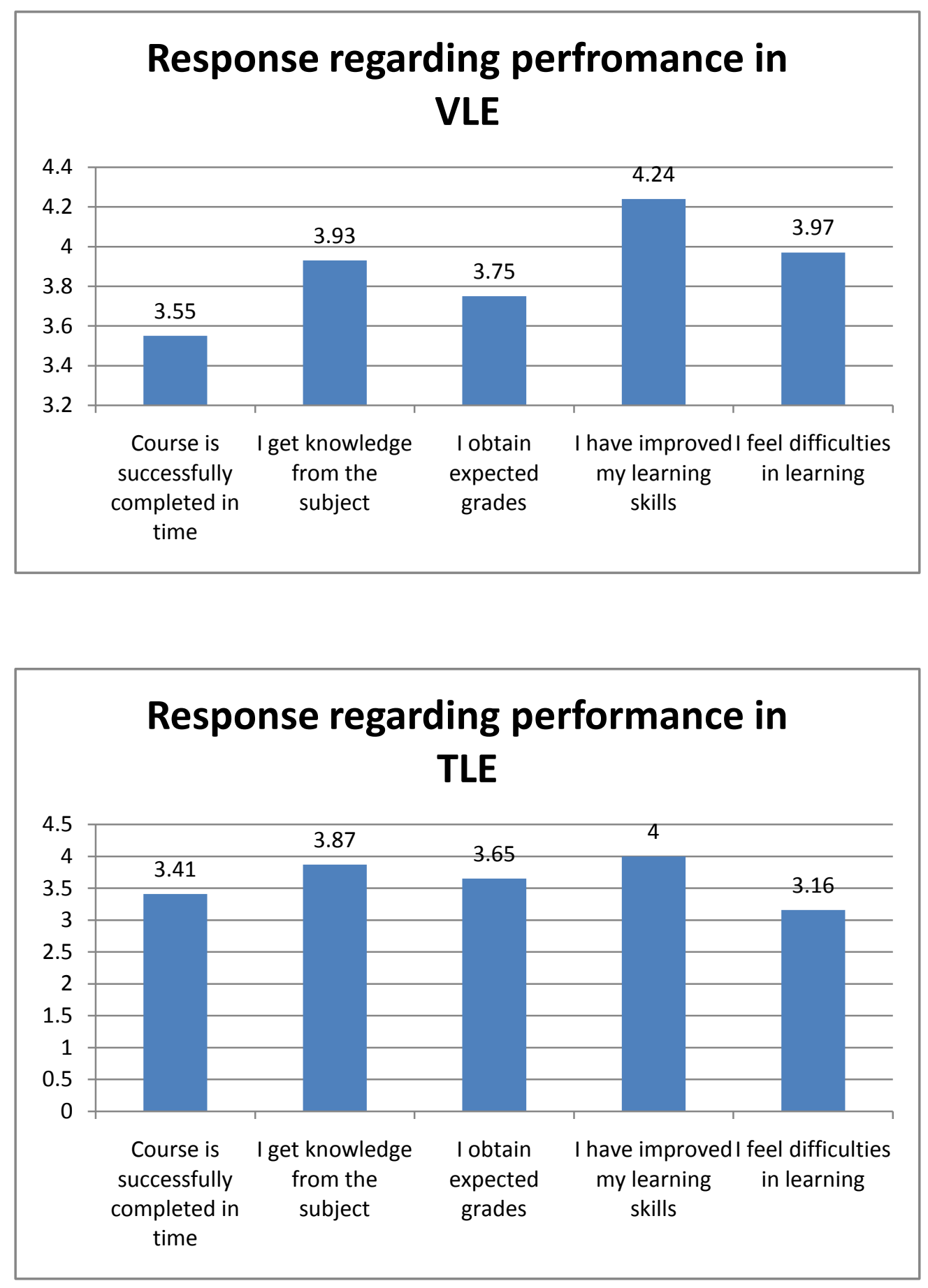
